\title{
Analysis of Triticum aestivum seedling response to the excess of zinc
}

\author{
Slawa Glińska $^{1}$ - Magdalena Gapińska ${ }^{1}$ - Sylwia Michlewska ${ }^{1}$ Elżbieta Skiba ${ }^{2}$. \\ Jakub Kubicki ${ }^{2}$
}

Received: 18 December 2014 / Accepted: 6 April 2015 /Published online: 24 April 2015

(C) The Author(s) 2015. This article is published with open access at Springerlink.com

\begin{abstract}
The effects of 50 and $300 \mathrm{mg} \mathrm{L}^{-1} \mathrm{Zn}^{2+}$ (50 $\mathrm{Zn}$ and $300 \mathrm{Zn}$ ) were investigated in Triticum aestivum (cv. Żura) grown hydroponically for 7 days. Although wheat treated with $50 \mathrm{Zn}$ took up relatively high amount of the metal $(8,943$ and $1,503 \mathrm{mg} \mathrm{kg}^{-1} \mathrm{DW}$ in roots and shoots, respectively), none of the morphological and cytological parameters were changed. After $300 \mathrm{Zn}$, the metal concentration increased to 32,205 and $5,553 \mathrm{mg} \mathrm{kg}^{-1} \mathrm{DW}$ in roots and shoots, respectively. It was connected with the depletion of shoot and root growth, their fresh and dry weight, water content and mitotic index of root meristematic cells. Microelement contents $(\mathrm{Cu}, \mathrm{Mn}$ and $\mathrm{Fe})$ after $50 \mathrm{Zn}$ were changed only in roots, while $300 \mathrm{Zn}$ disturbed ion balance in whole plants. The most evident ultrastructural alterations of root meristematic cells caused by both tested $\mathrm{Zn}^{2+}$ doses included increased vacuolization, accumulation of granular deposits inside vacuoles and cell wall thickening. The effect of $300 \mathrm{Zn}$ on root cell ultrastructure was greater that of $50 \mathrm{Zn}$. The majority of mitochondria had condensed matrix and swollen cristae, plastids contained plastoglobuli, nucleoli were ring-shaped, thinned down cytoplasm with lipid droplets and swollen endoplasmic reticulum cisternae appeared. In mesophyll cells, $50 \mathrm{Zn}$ caused slight reorganization of chloroplast thylakoids and formation of condensed mitochondria. Three hundred $\mathrm{Zn}$ triggered more
\end{abstract}

Handling Editor: Néstor Carrillo

Sława Glińska

slawa@biol.uni.lodz.pl

1 Laboratory of Microscopy Imaging and Advanced Biological Technics, Faculty of Biology and Environmental Protection, University of Lodz, Banacha 12/16, 90-237 Lodz, Poland

2 Institute of General and Ecological Chemistry, Lodz University of Technology, Żeromskiego 116, 90-924 Lodz, Poland extensive, but not degenerative, changes: plasmolysis of some cells; chloroplasts with protrusions, changed thylakoid organisation and often large starch grains; irregular, condensed mitochondria. The results indicate that $T$. aestivum cv. Żura is relatively tolerant to $\mathrm{Zn}$ stress.

Keywords Zinc toxicity · Wheat · Growth parameters · Mitotic index · Microelement content $\cdot$ Ultrastructure

\section{Introduction}

Zinc $(\mathrm{Zn})$ is an essential element for all organisms because it is a structural constituent and regulatory co-factor in enzymes involved in many biochemical pathways (Broadley et al. 2007). Zn deficiency is currently listed as a high-risk factor for human health (Broadley et al. 2007). It occurs predominantly in the regions where soils are poor in available $\mathrm{Zn}$, and cereals cultivated there are the major source of calorie intake (Alloway 2008). It is, therefore, highly important to develop quick solutions to the $\mathrm{Zn}$-deficiency problem and increase $\mathrm{Zn}$ concentration in crops. The dietary $\mathrm{Zn}$ intakes can be improved through biofortification of edible crops. Wheat is the staple food crop for $35 \%$ of the world's population and provides more calories and protein in total than any other crop. The application of $\mathrm{Zn}$-containing fertilizers increases the concentration of $\mathrm{Zn}$ in wheat grain up to threefold (Cakmak 2009).

Zinc, together with other plant micronutrients, can limit growth when it is present both at low and at excessive concentrations due to deficiency and toxicity, respectively. High concentrations of available zinc in soils usually arise from various sources of pollution, including atmospheric deposition from a nearby industrial source, such as smelting works, flooding of alluvial soils with zinc-polluted water and 
sediments, excessive applications of zinc rich materials, including pig and poultry manures from animals fed additional zinc, and high zinc sewage sludge or industrial waste waters (Alloway 2008; Tsonev and Lidon 2012). Zn concentration in municipal sewage sludge used as organic soil fertilizers can reach $1,000 \mathrm{mg} \mathrm{kg}^{-1}$ (Gondek et al. 2012). Although the accumulation of zinc to potentially toxic levels in crops is a small probability, it is important to constantly monitor the ion level in fertilized soil and in plants growing on it.

The Institute of Soil Science and Plant Cultivation (IUNG) determined threshold values of $\mathrm{Zn}$ concentration in agricultural light soils from $50 \mathrm{mg} \mathrm{kg}^{-1}$ of dry soil matter in soils of class 0 (natural content) to $300 \mathrm{mg} \mathrm{kg}^{-1}$ in soils of class II (slightly contaminated soils that could be used for agriculture; Szczepocka 2005).

$\mathrm{Zn}$ toxicity symptoms in plants usually occur when $\mathrm{Zn}$ leaf concentration is above $300 \mathrm{mg} \mathrm{kg}^{-1} \mathrm{DW}$, although toxicity thresholds can be highly variable even within the same species (Broadley et al. 2007). There are species that tolerate significantly higher $\mathrm{Zn}$ levels in their tissues. The concentration of $\mathrm{Zn}$ in plants growing in the polluted area near the Biała river in Silesian Voivodeship in Poland highly exceeded that value without serious symptoms of toxicity, e.g. Mentha aquatica leaves $576 \mathrm{mg} \mathrm{kg}^{-1}$ DW and Carex sp. roots $6,500 \mathrm{mg} \mathrm{kg}^{-1}$ DW (Szczepocka 2005).

Within the same species, significant differences may occur as far as $\mathrm{Zn}$ sensitivity is concern. A Zn-hyperaccumulating ecotype of Sedum alfredi grew well without any obvious change when exposed to $\mathrm{Zn}$ up to $500 \mu \mathrm{M}$, while toxic effects such as extremely stunted roots, thickened cuticule and cracked, brown and wilted leaves were observed in a nonZn-hyperaccumulating ecotype of this species exposed to $50 \mu \mathrm{M}$ Zn (Jin et al. 2008).

The aim of this study was to determine the morphological, cytological and ultrastructural effects of $\mathrm{Zn}^{2+}$ at the concentrations of 50 and $300 \mathrm{mg} \mathrm{L}^{-1}$ on Triticum aestivum (cv. Żura), an important crop plant, growing hydroponically under controlled laboratory conditions.

\section{Material and methods}

\section{Plant material and treatment}

Seeds of $T$. aestivum (cv. Żura) were surface sterilized with $70 \%$ ethanol for $10 \mathrm{~min}$, and then rinsed extensively with distilled water. Subsequently, they were placed on moistened filter paper in petri dishes to germinate in the darkness at $22^{\circ} \mathrm{C}$ for 2 days. Then seedlings were hydroponically grown for 7 days on aerated Hoagland solution containing: $\mathrm{KNO}_{3}$ $\left(0.51 \mathrm{~g} \mathrm{~L}^{-1}\right), \mathrm{Ca}\left(\mathrm{NO}_{3}\right)_{2} \times 4 \mathrm{H}_{2} \mathrm{O}\left(1.18 \mathrm{~g} \mathrm{~L}^{-1}\right), \mathrm{MgSO}_{4} \times 7 \mathrm{H}_{2} \mathrm{O}$ $\left(0.49 \mathrm{~g} \mathrm{~L}^{-1}\right), \mathrm{KH}_{2} \mathrm{PO}_{4}\left(0.14 \mathrm{~g} \mathrm{~L}^{-1}\right), \mathrm{H}_{3} \mathrm{BO}_{3}\left(0.6 \mathrm{mg} \mathrm{L}^{-1}\right)$, $\mathrm{MnCl}_{2} \times 4 \mathrm{H}_{2} \mathrm{O}\left(0.4 \mathrm{mg} \mathrm{L}^{-1}\right), \mathrm{ZnSO}_{4} \times 7 \mathrm{H}_{2} \mathrm{O}\left(0.05 \mathrm{mg} \mathrm{L}^{-1}\right)$,
$\mathrm{CuSO}_{4} \times 5 \mathrm{H}_{2} \mathrm{O}\left(0.05 \mathrm{mg} \mathrm{L}^{-1}\right)$, FeEDTA $\left(10.28 \mathrm{mg} \mathrm{L}^{-1}\right)$ and $\mathrm{Na}_{2} \mathrm{MoO}_{4} \times 2 \mathrm{H}_{2} \mathrm{O}\left(0.2 \mathrm{mg} \mathrm{L}{ }^{-1}\right)$ at $\mathrm{pH} 6.5$ and cultured at $21{ }^{\circ} \mathrm{C}$. The plants were growing under controlled conditions: light intensity of $170 \mu \mathrm{E} \mathrm{m}^{-2} \mathrm{~s}^{-1}, 16 / 8$-h day/night photoperiod and temperature $21{ }^{\circ} \mathrm{C}$ for 4 days. The growth medium was changed every $48 \mathrm{~h}$. After that time, the material was treated with $400 \mathrm{~mL}$ of the medium supplemented with $\mathrm{Zn}^{2+}$ to the concentrations of 50 and $300 \mathrm{mg} \mathrm{L}^{-1}$ ( 25 plants each). Plants cultured in standard Hoagland solution were the control. The solutions were changed every $24 \mathrm{~h}$. The experiment was repeated six times.

\section{Growth parameters}

Root and shoot growth was determined after 1, 3 and 7 days of incubation by subtracting the length of roots/shoots before incubation from that after incubation. Shoot and root fresh (FW) and dry weight (DW) were evaluated at the end of the experiment (7th day). To estimate DW, the plant material was dried for 2 days at $60{ }^{\circ} \mathrm{C}$.

\section{Water content}

The water content (WC) was calculated from FW and DW values according to the equation:

$[\%] \mathrm{WC}=(\mathrm{FW}-\mathrm{DW}) \times \mathrm{FW}^{-1} \times 100$

\section{Mitotic index}

Mitotic index of root meristematic cells was determined after 1,3 and 7 days of the experiment. Root meristems, 10 per each experimental series, after fixation in Carnoy's solution, were stained with Schiff reagent and squashed specimens were made. Subsequently, mitotic index (MI) was calculated according to the equation:

$[\%] \mathrm{MI}=$ the number of dividing cells $/$ the number of scored cells $(1000$ per root $) \times 100$

\section{Microelement analysis}

In order to determine contents of zinc and other essential microelements $(\mathrm{Cu}, \mathrm{Mn}$ and $\mathrm{Fe})$ in roots and shoots, $0.2 \mathrm{mg}$ of dried plant material (washed in deionized water before drying) was digested with the mixture of $6 \mathrm{~mL}$ of concentrated $\mathrm{HNO}_{3}$ and $1 \mathrm{~mL}$ of $30 \% \mathrm{HCl}$ in a closed system at $240{ }^{\circ} \mathrm{C}$ in a microwave oven Multivawe 3000 (Anton Paar) for $50 \mathrm{~min}$. The concentration of $\mathrm{Zn}$ was determined by Flame Atomic Absorption Spectrometry (FAAS) using (GBC 932 plus, 
Australia). Calibration was made using a multi-element standard (Merck).

\section{Transmission electron microscopy (TEM)}

From the control and treated plants, small portions of five leaves were cut from their central parts and five root meristems were cut off from different plants. The lamina samples were fixed in $3 \%$ glutaraldehyde in $0.1 \mathrm{M}$ cacodylate buffer $\mathrm{pH} 6.8$, for $3 \mathrm{~h}$, and the roots in $2 \%$ glutaraldehyde in $0.1 \mathrm{M}$ cacodylate buffer $\mathrm{pH} 7.2$, for $2 \mathrm{~h}$, both at $4{ }^{\circ} \mathrm{C}$. Subsequently, they were rinsed with the same buffer and post-fixed in osmium tetraoxide (the leaves in $2 \%$ and the roots in $1 \%$ solution) for $2 \mathrm{~h}$ at $4{ }^{\circ} \mathrm{C}$. The material was dehydrated in a graded ethanol series and embedded in Epon-Spur's resin mixture. The 80-nm-thick cross sections of the leaves and longitudinal sections of the roots were obtained with an ultramicrotome (Ultracut E, Reichert Yung, Germany). The ultrathin sections were placed on formvar-coated nickel grids and stained with a saturated solution of uranyl acetate, and subsequently, with lead citrate (Reynolds 1963). The cell ultrastructure was analysed on TEM (JEM 1010, JEOL, Japan) at $80 \mathrm{kV}$.

\section{Statistical analysis}

The data are shown as means with the standard error (SE). The significance of differences between treatments was determined by the $t$ Student test. Differences at $p \leq 0.05$ were considered statistically significant.

\section{Results}

\section{Growth parameters}

Fifty $\mathrm{Zn}$ did not affect root growth during a 7-day treatment (Fig. 1a). After 1, 3 and 7 days of the experiment, the root length increased similarly as in the control material by approximately 10, 30 and $50 \mathrm{~mm}$, respectively. The shoot growth decreased slightly (by $17 \%$ ) on the third day of experiment; but after longer exposure to $50 \mathrm{Zn}$, it did not differ significantly from the control material (Fig. 1b).

The root and shoot growth of $T$. aestivum was strongly impaired by $300 \mathrm{Zn}$ (Fig. 1). The root growth fell dramatically after the 1st day of treatment (by $74 \%$ ), and the effect persisted causing 82 and $85 \%$ decreases after 3rd and 7th day, respectively (Fig. 1a). The wheat shoots were slightly less sensitive to high $\mathrm{Zn}$ dose than roots; however, their growth was also reduced already after 1 day of experiment (by $36 \%$ ). The decrease in shoot growth after 3rd and 7th day of treatment amounted to 50 and $63 \%$, respectively (Fig. 1b).

Root and shoot biomass production was estimated after 7 days of experiment. The low $\mathrm{Zn}$ dose did not change these
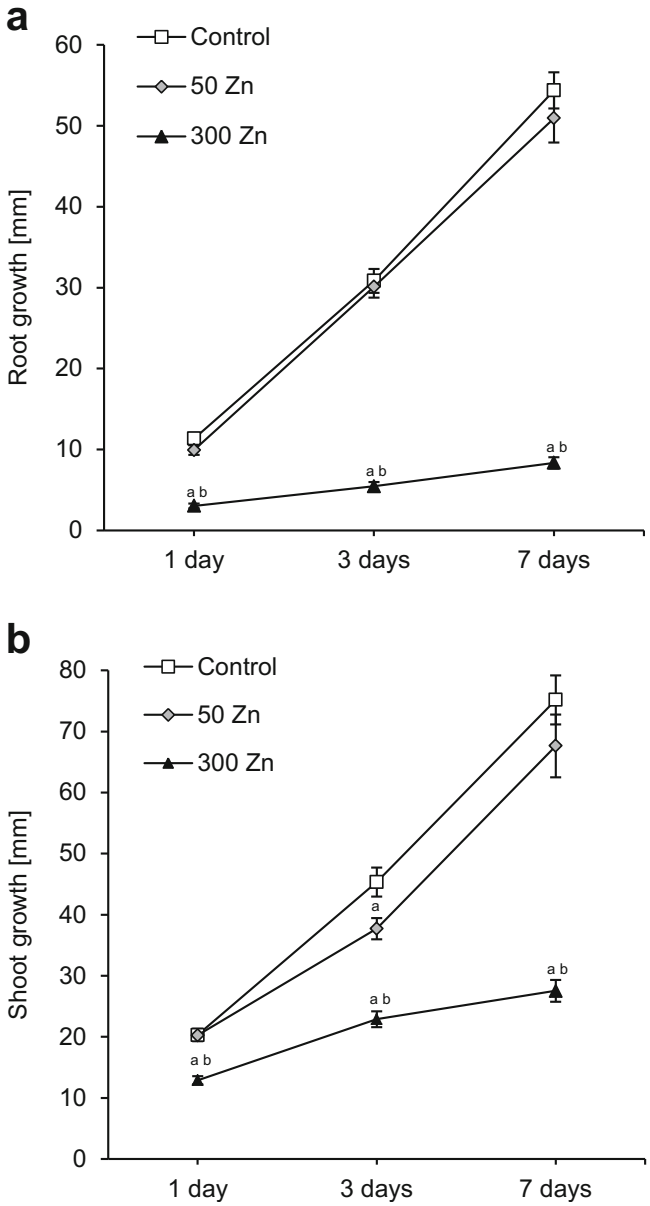

Fig. 1 The effect of 50 and $300 \mathrm{mg} \mathrm{L}^{-1} \mathrm{Zn}$ on root (a) and shoot (b) growth rate of Triticum aestivum plants during a 7-day treatment. Values are means of 60 measurements (6 replicates with 10 plants), and vertical bars represent SE. $a$ denotes significant differences between $\mathrm{Zn}$-treated plants and the control, and $b$ between 50 and $300 \mathrm{Zn}$ variants at $p \leq 0.05$

parameters as compared to the control (Figs. 2 and 3). FW and DW were reduced significantly following $300 \mathrm{Zn}$ treatment (Figs. 2 and 3), with the roots being affected more than the shoots. The FW and DW of the former dropped to 54 and $66 \%$ of the control while the respective values for the latter to 62 and $80 \%$ (Figs. 2 and 3).

\section{Water content}

WC in both analysed organs of T. aestivum was not changed by $50 \mathrm{Zn}$ treatment; however, the higher $\mathrm{Zn}$ concentration diminished this parameter to 78 and to $74 \%$ of the values noted in the control roots and shoots, respectively (Fig. 4).

\section{Mitotic index}

Similarly as in the case of root growth, treatment with the lower dose of $\mathrm{Zn}$ did not significantly affect $\mathrm{MI}$ in root-tip cells throughout the experiment, while $300 \mathrm{Zn}$ reduced the 


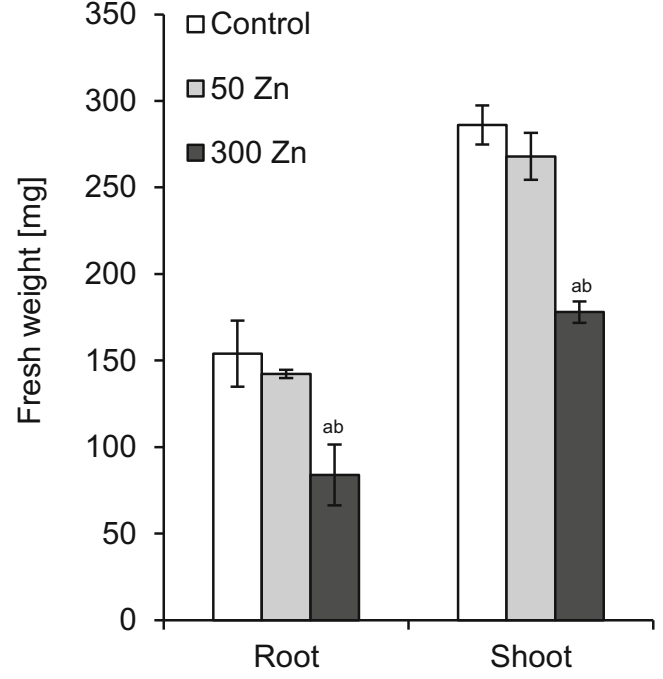

Fig. 2 The effect of 50 and $300 \mathrm{mg} \mathrm{L}^{-1} \mathrm{Zn}$ on root and shoot fresh weight of Triticum aestivum plants after a 7-day treatment. Values are means of six replicates, and vertical bars represent SE. $a$ denotes significant differences between $\mathrm{Zn}$-treated plants and the control, and $b$ between 50 and $300 \mathrm{Zn}$ variants at $p \leq 0.05$

value of this parameter by 64,61 and $83 \%$, after 1,3 and 7 days, respectively, as compared to the control (Fig. 5).

\section{Microelement analysis}

The contents of $\mathrm{Zn}$ in T. aestivum cultivated under the control conditions were 145.6 and $60.6 \mathrm{mg} \mathrm{kg}^{-1} \mathrm{DW}$ in roots and shoots, respectively (Table 1). Also other analysed microelements $(\mathrm{Cu}, \mathrm{Mn}$ and $\mathrm{Fe})$ were more abundant in the roots (Table 1).

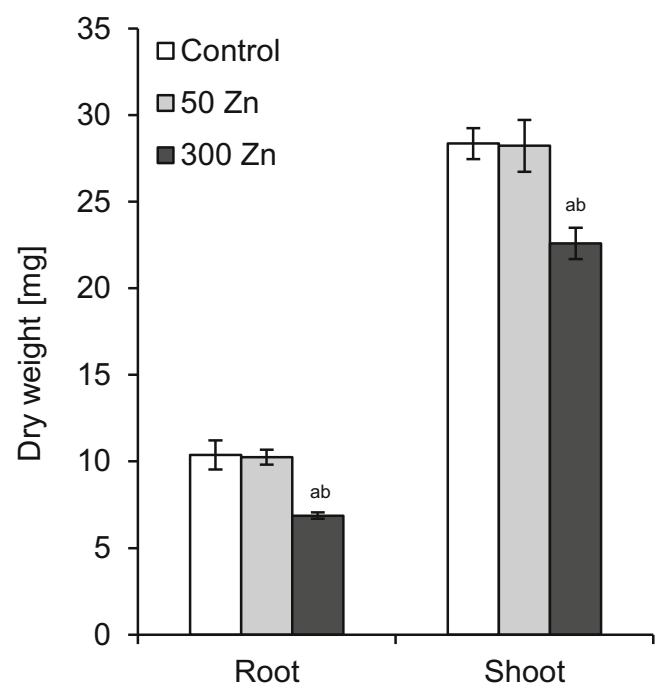

Fig. 3 The effect of 50 and $300 \mathrm{mg} \mathrm{L}^{-1} \mathrm{Zn}$ on root and shoot dry weight of Triticum aestivum plants after a 7-day treatment. Values are means of six replicates, and vertical bars represent SE. $a$ denotes significant differences between $\mathrm{Zn}$-treated plants and the control, and $b$ between 50 and $300 \mathrm{Zn}$ variants at $p \leq 0.05$

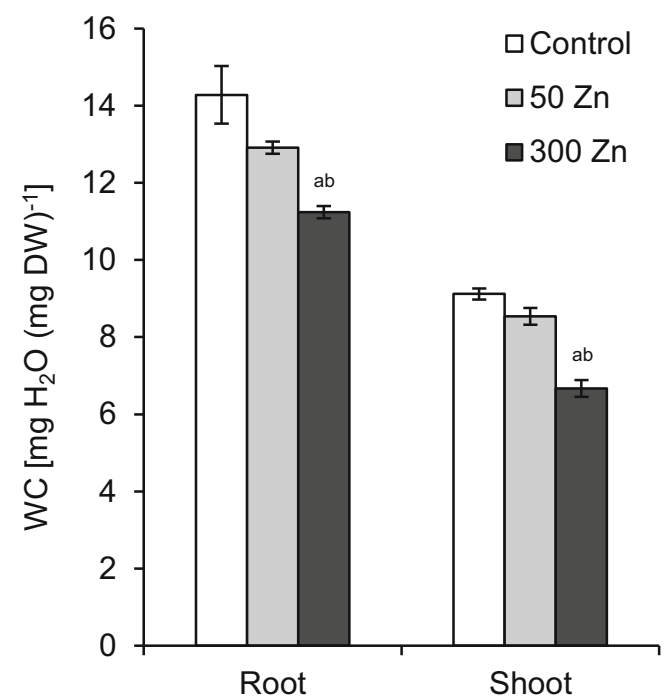

Fig. 4 The effect of 50 and $300 \mathrm{mg} \mathrm{L}^{-1} \mathrm{Zn}$ on root and shoot water content (WC) of Triticum aestivum plants after a 7-day treatment. Values are means of six replicates, and vertical bars represent SE. a denotes significant differences between $\mathrm{Zn}$-treated plants and the control, and $b$ between 50 and $300 \mathrm{Zn}$ variants at $p \leq 0.05$

Fifty $\mathrm{Zn}$ significantly enhanced this ion content, the 25 -fold and 61-fold increases were observed in the shoots and roots, respectively. However, other microelement concentrations were changed in the roots, but not in the shoots (Table 1). Fifty $\mathrm{Zn}$ increased $\mathrm{Cu}$ and $\mathrm{Fe}$ absorption by the roots up to 272 and $161 \%$ of the control, respectively. Mn ion content in the roots decreased to $19 \%$ of the control value.

Three hundred $\mathrm{Zn}$ drastically raised the $\mathrm{Zn}$ content both in the roots (221-fold) and in the shoots (92-fold; Tab. 1). The other microelement concentrations were also affected both in the roots and the shoots (Table 1). In the shoots, $\mathrm{Cu}, \mathrm{Mn}$ and Fe concentrations declined to 36,61 and $65 \%$ of the control, respectively. In the roots, $\mathrm{Mn}$ content drastically diminished to

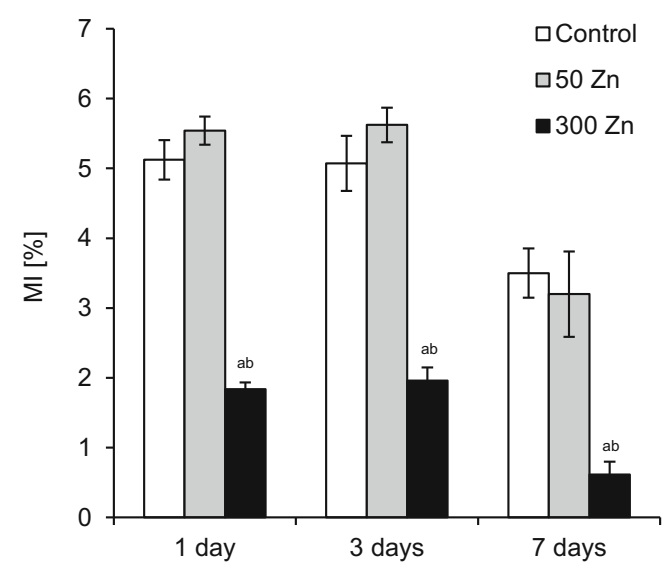

Fig. 5 The effect of 50 and $300 \mathrm{mg} \mathrm{L}^{-1} \mathrm{Zn}$ on mitotic index (MI) of root meristematic cells of Triticum aestivum plants during a 7-day treatment. Values are means of 10 replicates, and vertical bars represent SE. a denotes significant differences between $\mathrm{Zn}$-treated plants and the control, and $b$ between 50 and $300 \mathrm{Zn}$ variants at $p \leq 0.05$ 
Table 1 The effect of 50 and $300 \mathrm{mg} \mathrm{L}^{-1} \mathrm{Zn}^{2+}$ on microelement content in shoot and root of Triticum aestivum plants after a 7-day treatment

\begin{tabular}{|c|c|c|c|c|c|}
\hline & & \multicolumn{4}{|c|}{ Microelement content $\left[\mathrm{mg} \mathrm{kg}^{-1} \mathrm{DW}\right]$} \\
\hline & & $\mathrm{Zn}$ & $\mathrm{Cu}$ & $\mathrm{Mn}$ & $\mathrm{Fe}$ \\
\hline \multirow[t]{2}{*}{ Control } & Shoot & $60.6 \pm 27.2$ & $9.7 \pm 3.2$ & $15.6 \pm 5.5$ & $30.0 \pm 5.5$ \\
\hline & Root & $145.6 \pm 43.2$ & $27.0 \pm 11.8$ & $68.5 \pm 11.2$ & $33.1 \pm 2.0$ \\
\hline \multirow[t]{2}{*}{$50 \mathrm{Zn}$} & Shoot & $1,503.3 \pm 178.4 \mathrm{a}$ & $6.1 \pm 1.0$ & $11.6 \pm 4.9$ & $27.9 \pm 1.9$ \\
\hline & Root & $8,942.9 \pm 547.1 \mathrm{a}$ & $73.4 \pm 17.3 \mathrm{a}$ & $12.7 \pm 6.6 \mathrm{a}$ & $53.3 \pm 1.4 \mathrm{a}$ \\
\hline \multirow[t]{2}{*}{$300 \mathrm{Zn}$} & Shoot & $5,553.1 \pm 576.8 \mathrm{ab}$ & $3.5 \pm 1.4 \mathrm{ab}$ & $9.5 \pm 2.3 \mathrm{a}$ & $19.6 \pm 4.7 \mathrm{ab}$ \\
\hline & Root & $32,205.2 \pm 8928.4 \mathrm{ab}$ & $109.0 \pm 5.3 \mathrm{ab}$ & $4.3 \pm 1.6 \mathrm{a}$ & $679.0 \pm 97.8 \mathrm{ab}$ \\
\hline
\end{tabular}

Each value represents a mean of 3 replicates \pm SE. The $a$ denote significant differences of $\mathrm{Zn}$-treated plants from control and $b$ between 50 and $300 \mathrm{Zn}$ variants at $p \leq 0.05$

$6 \%$ of the control while those of $\mathrm{Cu}$ and Fe significantly raised (4-fold and 20-fold, respectively).

\section{TEM}

Ultrastructure of meristematic cells of the control wheat roots on the 7th day of the experiment was typical (Fig. 6). The central part of the cell was occupied by a nucleus with 1-3 nucleoli (Fig. 6a). The level of cell vacuolization was low and small vacuoles were electron-transparent (Fig. 6a, b). Plastids had electron-dense stroma and rare thylakoids, small starch grains were seen sporadically, and no plastoglobuli were visible (Fig. 6b, c). Mitochondria displayed electron-transparent matrix and usually narrow cristae (Fig. 6b-d). Single endoplasmic reticulum cisternae were running in different directions (Fig. 6b-d). Golgi apparatus was composed of 5-6 cisternae and a few vesicles (Fig. 6d). Cell wall was thin with visible plasmodesmata (Fig. 6c).

Fifty $\mathrm{Zn}$-enhanced cell vacuolization. The vacuoles were filled with countless small granules and frequently large electron-dense deposits occurred (Fig. 7a, b). There were many typical mitochondria (Fig. 7c), but sometimes they turned into a condensed form, i.e. with electron-dense matrix and numerous swollen cristae (Fig. 7b, d). Golgi apparatus cisternae with numerous vesicles around them were visible in the cytoplasm (Fig. 7b, d). Plastids had electron-dense stroma with few thylakoids (Fig. 7d). Cell wall was thicker and sometimes slightly wavy (Fig. 7c).

Three hundred Zn significantly affected root cell ultrastructure. It triggered far more extensive vacuolization than the lower $\mathrm{Zn}$ dose. After 7 days of treatment, large vacuoles were packed with numerous huge electron-dense deposits (Fig. 8ac). Small granules were also seen in irregularly thickened cell wall (Fig. 8b, c). The majority of mitochondria were in condensed form (Fig. 8d). Plastids contained plastoglobuli (Fig. 8d). The cytoplasm was thinned down in some cells, and lipid droplets were seen in it (Fig. 8b-d). Sometimes swollen endoplasmic reticulum cisternae, and quite frequent ring-shaped nucleoli occurred (Fig. 8a).

Ultrastructure of mesophyll cells of the control wheat leaves on 7th day of the experiment was typical with thin layer of cytoplasm surrounding the central transparent vacuole (Fig. 9a). Ellipsoid chloroplasts had regularly organized grana and starch grains were very rare and small. Mitochondria, oval in shape with matrix of electron-density similar to cytoplasm, had narrow cristae (Fig. 9a).

The mesophyll cells of the wheat leaves treated with $50 \mathrm{Zn}$ did not differ significantly from the control. Sometimes the cells contained chloroplasts with slightly changed organization of thylakoids and mitochondria with swollen cristae and condensed matrix (Fig. 9b).

Three $\mathrm{Zn}$ triggered far more extensive changes in the leaf mesophyll cell ultrastructure. Some cells had slightly thinned down cytoplasm and showed symptoms of plasmolysis (Fig. 9c, arrow). The vacuoles did not contain any electrondense deposits (Fig. 9c, d). Chloroplasts showed less regular shape, dense stroma and irregular thylakoid organisation (Fig. 9c). Moreover, specific protrusions containing thylakoid-free stroma were observed (Fig. 9c, d; asterisk). Many chloroplasts contained large starch grains (Fig. 9c). Two types of mitochondria were noticed: (i) similar to those in the control material (Fig. 9c) and (ii) changed in shape with swollen cristae and condensed matrix (Fig. 9d).

\section{Discussion}

Growth parameters are good indicators of stress, and their changes were noticed after plant exposure to different heavy metals (Sagardoy et al. 2009; Jain et al. 2010; Yang et al. 2011; Caldelas et al. 2012). In our experiment, a decline of FW and DW of shoots and roots as well as of their growth was observed after application of $300 \mathrm{Zn}$. Among the analysed parameters, the root growth was the most responsive one as after 7 days of treatment it decreased by $85 \%$ while FW and DW 

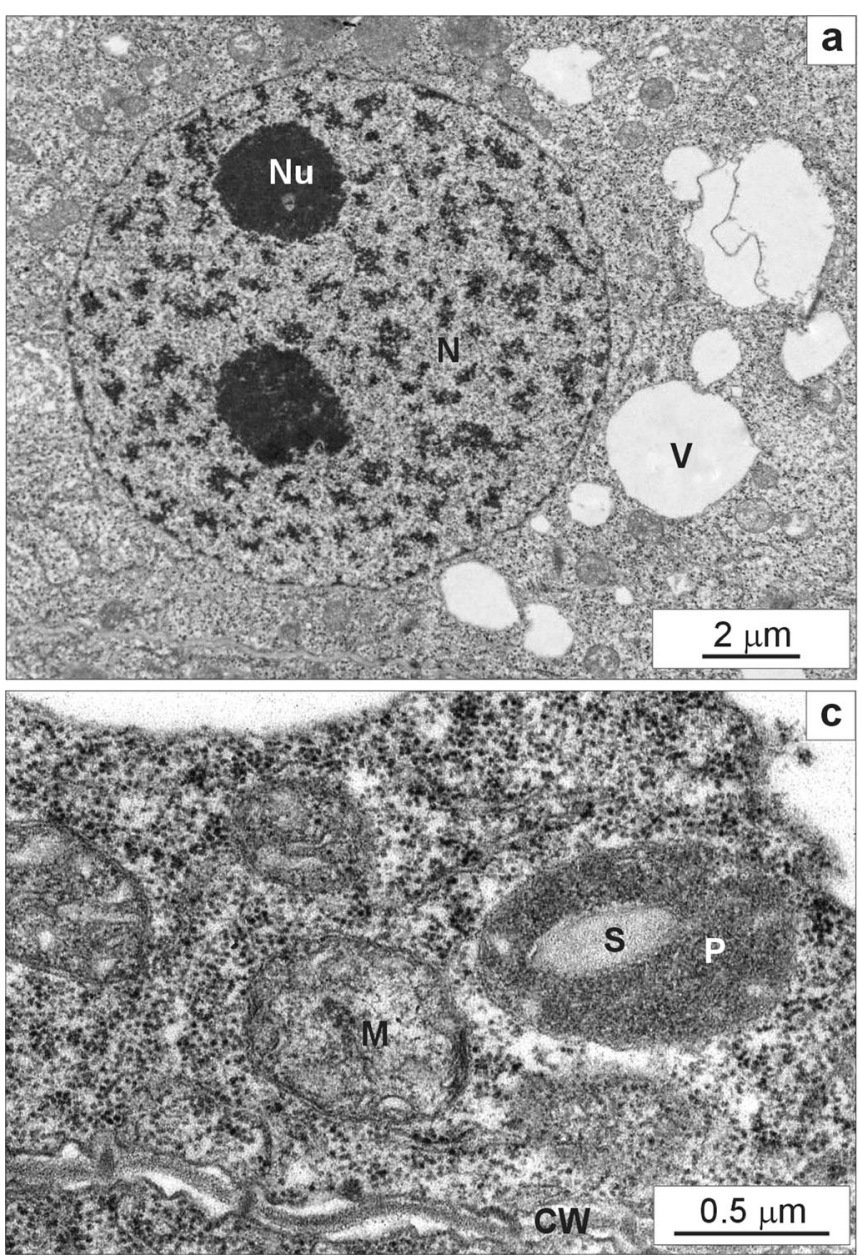

Fig. 6 The ultrastructure of root meristematic cells of the control Triticum aestivum plants after a 7-day hydroponic cultivation. The part of a cell with typical nucleolus containing two nucleoli and small electron-transparent vacuoles scattered in the cytoplasm (a). Mitochondria with low-density matrix and narrow cristae, a small plastid without starch, endoplasmic reticulum cisternae running in different directions and an electron-lucent vacuole (b). Mitochondria

only by 46 and $34 \%$, respectively. Much smaller amount of $\mathrm{Zn}$ was accumulated in the shoots, this might be the reason why the toxic effect was less evident in them.

The decline in biomass production might be explained by the inhibition of meristematic cell division and of elongation of root cells. $300 \mathrm{Zn}$-triggered sharp depression in the MI of wheat root meristematic cells just after 1 day of $\mathrm{Zn}$ application. Similarly, $88 \%$ inhibition of cell division in the presence of $\mathrm{Zn}$ at the concentration of $130 \mathrm{mg} \mathrm{L}^{-1}$ was observed in Saccharum spp (Jain et al. 2010).

The levels of $\mathrm{Zn}$ in plants usually range between 10 and $100 \mathrm{mg} \mathrm{kg}^{-1}$ of DW and toxicity symptoms usually become visible in crop species at $\mathrm{Zn}>300 \mathrm{mg} \mathrm{kg}^{-1}$ leaf DW (Broadley et al. 2007). In our experiment, the wheat cultivated in Hoagland solution (control) had $60 \mathrm{mg} \mathrm{Zn} \mathrm{per} \mathrm{kg} \mathrm{of} \mathrm{DW} \mathrm{of}$ shoot, and such an amount ensured optimal plant growth. Wheat has relatively high tolerance to $\mathrm{Zn}$. The plants treated
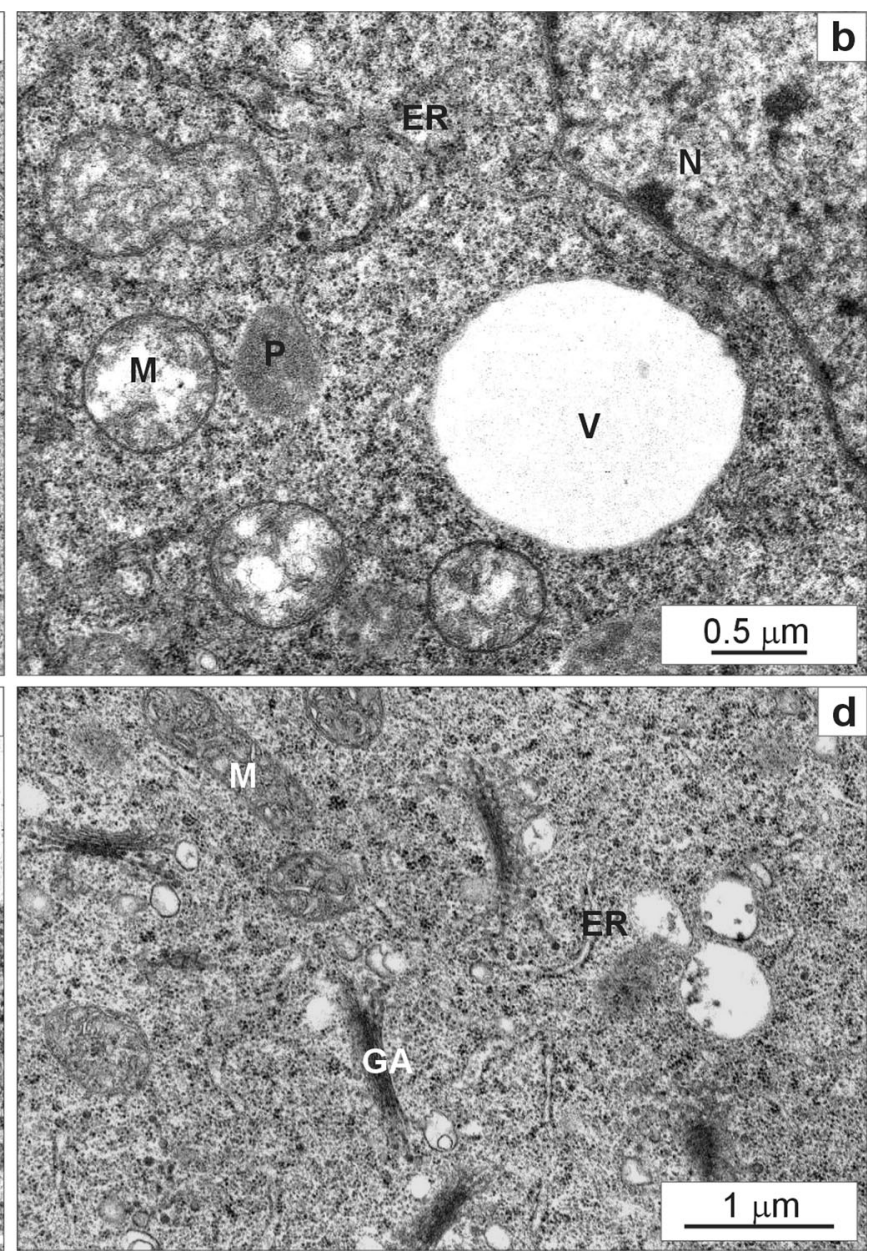

with numerous slightly widened cristae, a plastid with a starch grain, endoplasmic reticulum cisternae and a cell wall with visible plasmodesmata (c). Numerous active Golgi apparati with quite numerous vesicles, mitochondria with numerous slightly widened cristae, endoplasmic reticulum cisternae running in different directions (d). $C W$ cell wall, $E R$ endoplasmic reticulum, $G A$ Golgi apparatus, $M$ mitochondrium, $N$ nucleus, $N u$ nucleolus, $P$ plastid, $S$ starch, $V$ vacuole

with $50 \mathrm{Zn}$ contained $1,503 \mathrm{mg} \mathrm{Zn} \mathrm{kg}{ }^{-1}$ shoot DW and 8 , $942 \mathrm{mg} \mathrm{Zn} \mathrm{kg}^{-1}$ root DW but no toxicity symptoms were observed. Similarly to wheat, $A$. thaliana seedlings containing $1980 \mathrm{mg} \mathrm{Zn} \mathrm{kg}{ }^{-1}$ shoot DW were characterised by normal growth and lack of morphological symptoms of $\mathrm{Zn}$ toxicity (Richard et al. 2011). P. tomentosa grew at a nutrient solution containing similar $\mathrm{Zn}$ dose $(1,000 \mu \mathrm{M})$ was without any adverse effect but it absorbed a smaller amount of this microelement (about $1,000 \mathrm{mg} \mathrm{kg}^{-1}$ root DW and $400 \mathrm{mg} \mathrm{kg}^{-1}$ shoot DW) (Azzarello et al. 2012). Zn hyperaccumulator Arabis paniculata accumulated up to $10,000 \mathrm{mg} \mathrm{Zn} \mathrm{kg}{ }^{-1}$ shoot DW, and no biomass decrease was observed (Zeng et al. 2011). Wheat treated with $300 \mathrm{Zn}$ accumulated $5553 \mathrm{mg} \mathrm{Zn}$ $\mathrm{kg}^{-1}$ shoot DW and as much as $32205 \mathrm{mg} \mathrm{Zn} \mathrm{kg}{ }^{-1}$ root DW but this dose was highly toxic reducing FW and DW as well as decreasing root and shoot growth. The significant reduction of growth parameters (by about $60 \%$ ) in Saccharum spp. was 

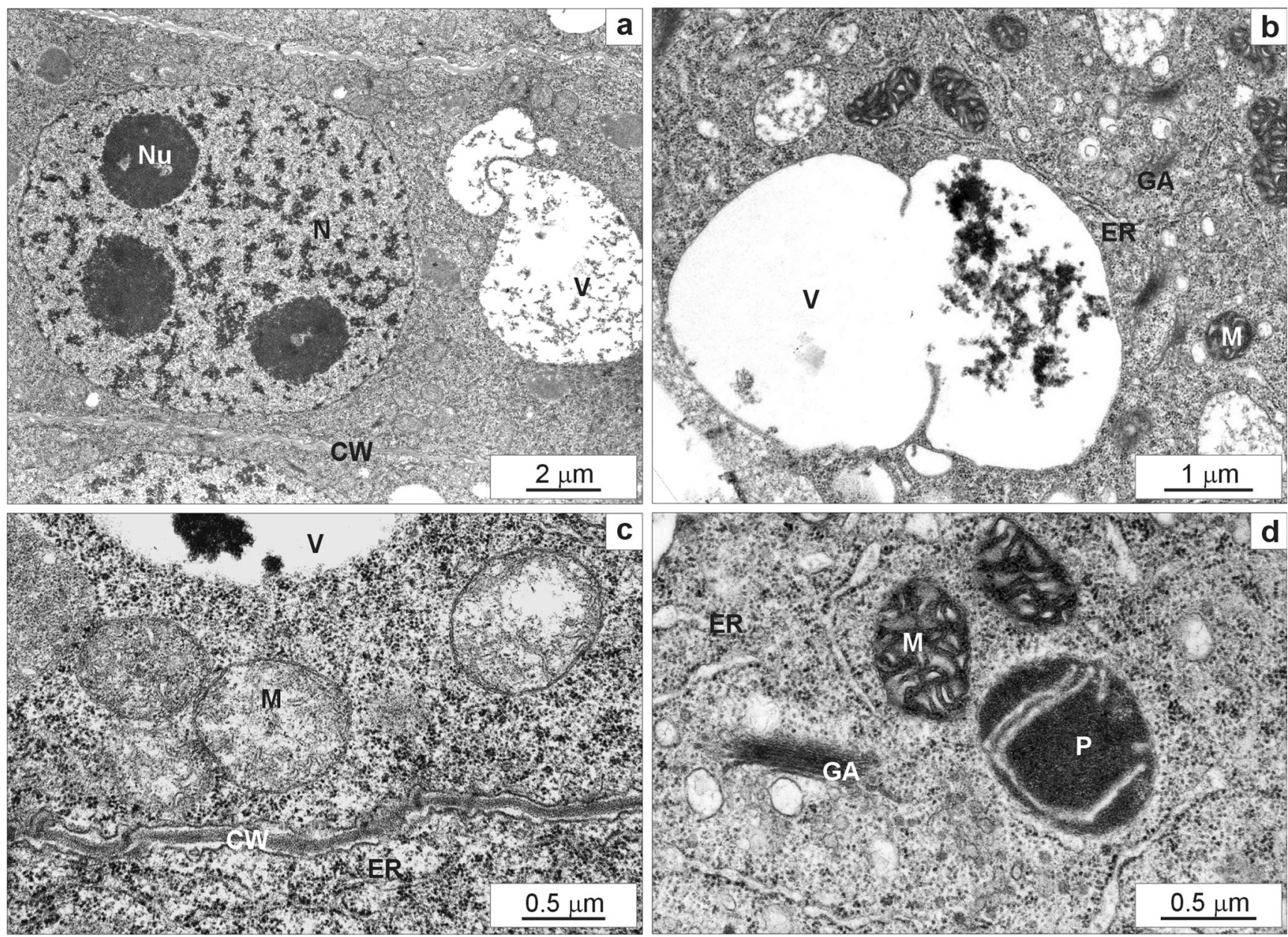

Fig. 7 The ultrastructure of root meristematic cells of Triticum aestivum plants after a 7-day treatment with $50 \mathrm{mg} \mathrm{L}^{-1} \mathrm{Zn}$. The part of a cell with typical nucleolus containing three nucleoli, large vacuoles containing numerous small granular deposits and a typical thin cell wall (a). A large vacuole containing electron-dense material, mitochondria with condensed matrix and numerous wide cristae, endoplasmic reticulum and numerous Golgi apparati visible in the cytoplasm (b). Mitochondria with low-density matrix and narrow cristae, endoplasmic reticulum

reported already at $130 \mathrm{mg} \mathrm{L}^{-1} \mathrm{Zn}$ concentration (Jain et al. 2010). Other species are more sensitive to $\mathrm{Zn}$ excess. The significant decrease in the total DW and leaf area of Paulownia tomentosa grown hydroponically was observed already at 2,000 $\mu \mathrm{M}$ Zn (Azzarello et al. 2012), whereas Pisum sativum became inhibited after 1,000 $\mu \mathrm{M} \mathrm{Zn}$ application (Doncheva et al. 2001).

$\mathrm{Zn}, \mathrm{Cu}, \mathrm{Mn}$ and $\mathrm{Fe}$ are the micronutrients which are essential for plants and their homeostasis seems to be very important (Palmer and Guerinot 2009). Supply of Zn into the growth medium affected $\mathrm{Cu}, \mathrm{Mn}$ and $\mathrm{Fe}$ accumulation in plants. In the roots their levels were changed after application of both tested $\mathrm{Zn}$ concentrations but in the shoots microelement content $(\mathrm{Cu}$, $\mathrm{Mn}$ and $\mathrm{Fe}$ ) decrease was triggered only by $300 \mathrm{Zn}$. The alterations in mineral content caused by $\mathrm{Zn}$ excess are often more evident in roots than in shoots (Caldelas et al. 2012; Jain cisternae, thin cell wall and a fragment of a vacuole with electron-dense material (c). Active Golgi apparatus with quite large vesicles, condensed type of mitochondria with numerous widened cristae, slightly swollen endoplasmic reticulum cisternae, a plastid with electron-dense stroma and a few thylakoids (d). $C W$ cell wall, $E R$ endoplasmic reticulum, $G A$ Golgi apparatus, $M$ mitochondrium, $N$ nucleus, $N u$ nucleolus, $P$ plastid, $S$ starch, $V$ vacuole

et al. 2010). While Mn concentration declined both in the shoots and roots of the wheat plants, $\mathrm{Cu}$ and $\mathrm{Fe}$ reduction in the shoots was accompanied by an increase in their concentration in the roots which suggests rather disturbances in their transport than depletion of their uptake. Similarly, in Beta vulgaris grown hydroponically with $\mathrm{Zn}$ up to $300 \mu \mathrm{M}$, Fe concentration decreased in shoots and increased in roots while $\mathrm{Mn}$ concentration declined in both plant organs (Sagardoy et al. 2009). Jain et al. (2010) after 65 and $130 \mathrm{mg} \mathrm{L}^{-1} \mathrm{Zn}^{2+}$ supplementation observed decrease in $\mathrm{Cu}$ content in Saccharum spp.; but contrary to our results, it concerned whole plants, not only shoots. Moreover, they noted decrease in $\mathrm{Fe}$ and slight increase in Mn contents in roots without significant changes of these ions contents in leaves after the higher $\mathrm{Zn}$ dose (Jain et al. 2010). 


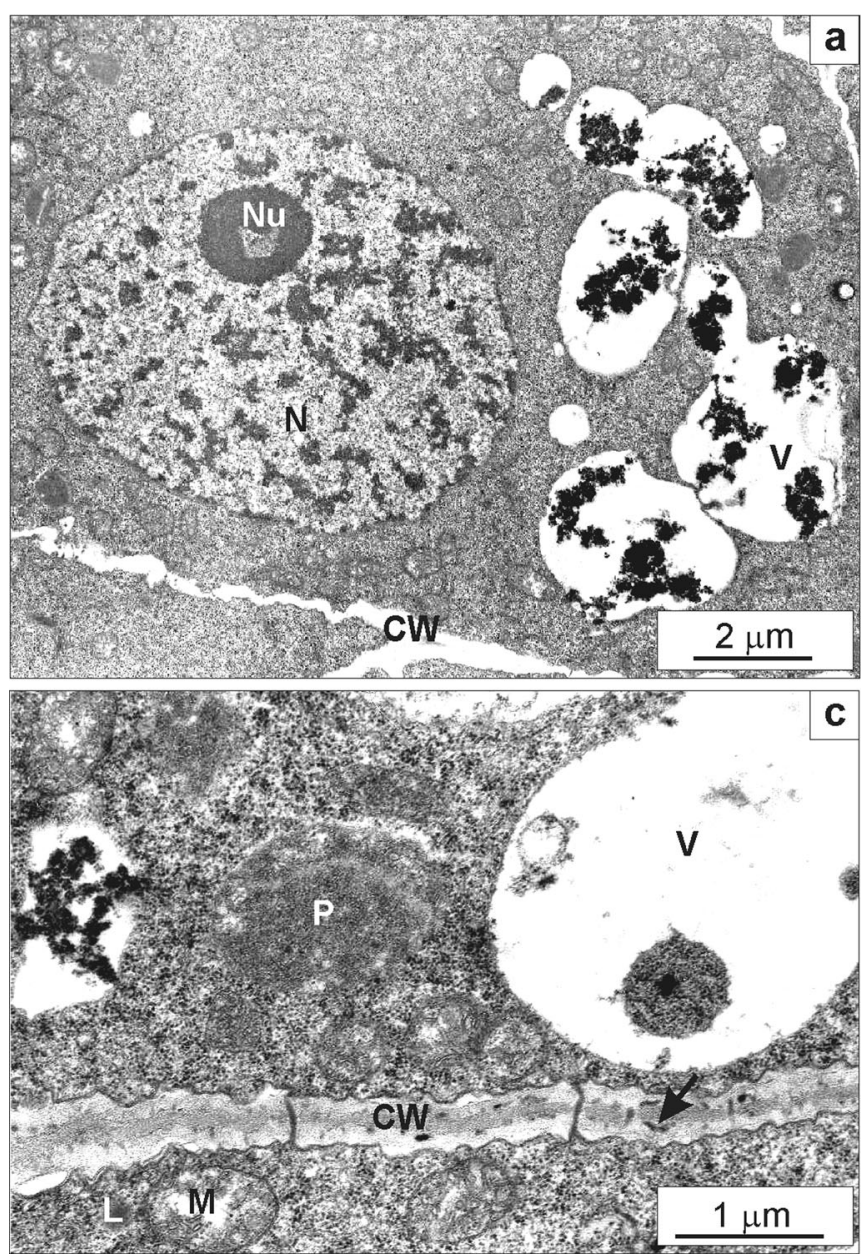

Fig. 8 The ultrastructure of root meristematic cells of Triticum aestivum plants after a 7-day treatment with $300 \mathrm{mg} \mathrm{L}^{-1} \mathrm{Zn}$. A nucleus containing nucleolus with a vacuole, large vacuoles containing numerous large electron-dense deposits and a wavy cell wall (a). Large vacuoles containing electron-dense material, a lipid droplet visible in the cytoplasm and a cell wall containing small electron-dense deposits (arrow; b). Mitochondria with low-density matrix and narrow cristae, a plastid without starch, a lipid droplet in the cytoplasm, a cell wall with

Nearly $90 \%$ of $\mathrm{Fe}$ in plants is localized in chloroplasts, where it is required for electron transport chain and synthesis of chlorophyll-determining proper course of photosynthesis and biomass production (Palmer and Guerinot 2009). The $45 \%$ decrease in Fe content in $T$. aestivum shoots may be one of the most important reasons of biomass production decline.

$\mathrm{Zn}$ overdose altered not only ion homeostasis but also water balance. In our experiment $300 \mathrm{Zn}$ caused significant decrease in water content both in the roots and shoots. The similar $\mathrm{Zn}$ dose (5 mM) also induced relative water content limitation in R. sativus plants (Ramakrishna and Rao 2014). The decline of water content in B. vulgaris plants was observed already at the concentration of $50 \mu \mathrm{M} \mathrm{Zn}$, however this species seems to be $\mathrm{Zn}$-sensitive because at this concentration all tested growth parameters decreased (Sagardoy et al. 2009).
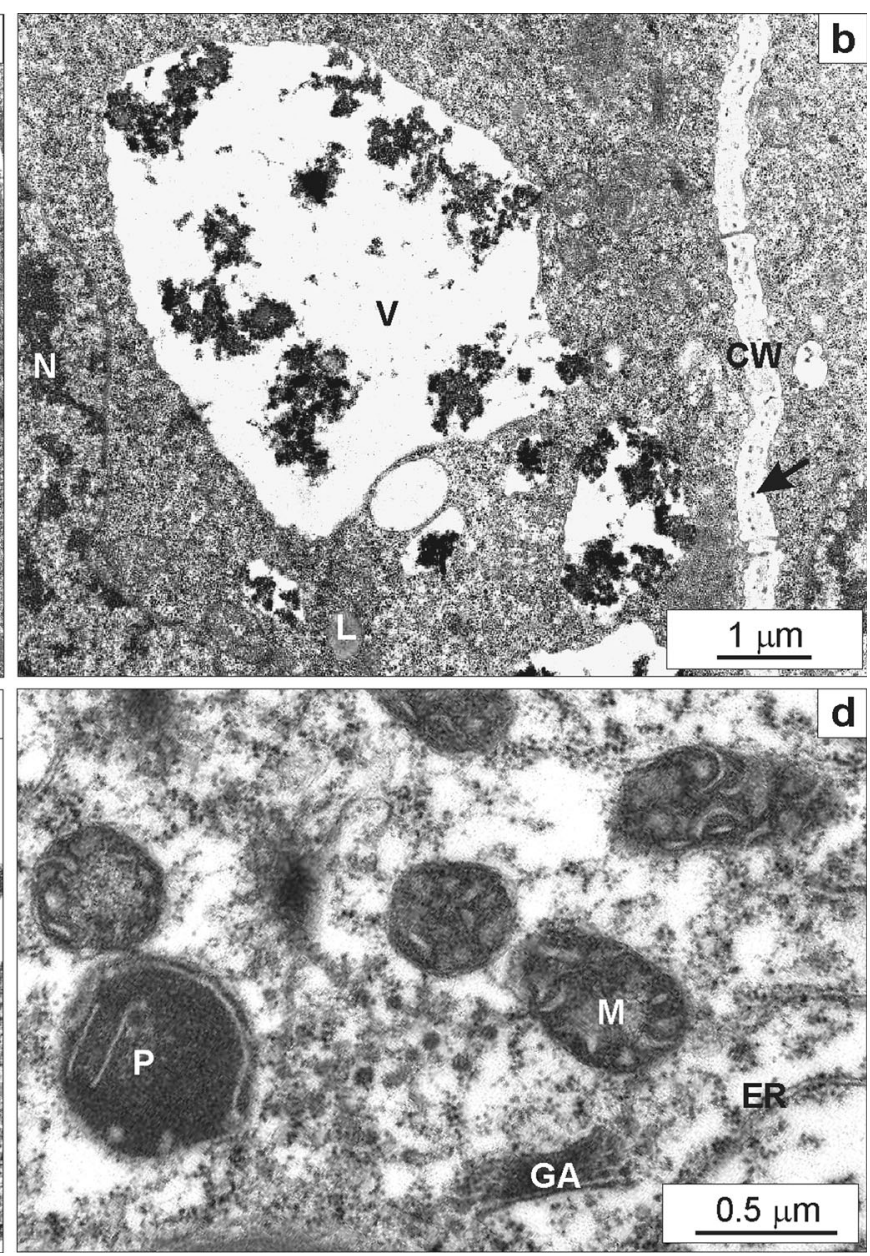

electron-dense deposits (arrow) and visible plasmodesmata, and fragments of vacuoles with electron-dense material (c). A fragment of a cell with thinned down cytoplasm, non-active Golgi apparatus without vesicles, condensed type of mitochondria, a plastid with electron-dense stroma and a few thylakoids and narrow endoplasmic reticulum cisternae (d). $C W$ cell wall, $E R$ endoplasmic reticulum, $G A$ Golgi apparatus, $L$ lipid, $M$ mitochondrium, $N$ nucleus, $N u$ nucleolus, $P$ plastid, $V$ vacuole

The effect of $\mathrm{Zn}$ excess on plant growth parameters and morphology has been widely studied (Richard et al. 2011; Yang et al. 2011; Caldelas et al. 2012; Mangal et al. 2013; Mukhopadhyay et al. 2013; Ramakrishna and Rao 2014), however the research at the ultrastructural level has been scarce (Azzarello et al. 2012; Reboredo 2012; Xu et al. 2013; Liu et al. 2014).

The most evident ultrastructural alterations of root meristematic cells of T. aestivum plants treated with both tested $\mathrm{Zn}$ doses included increased vacuolization and accumulation of granular electron-dense deposits inside vacuoles and thickened cell walls. Additionally in the material treated with 300 $\mathrm{Zn}$ small electron-dense deposits were present in a thickened cell wall. Similar electron-dense material in the form of clumps or globules was observed in vacuoles of root cortical cells of $P$. tomentosa grown at $1000 \mu \mathrm{M} \mathrm{Zn}$ and these 
Fig. 9 The ultrastructure of leaf mesophyll cells of Triticum aestivum plants after a 7-day treatment with 50 and $300 \mathrm{mg} \mathrm{L}^{-1} \mathrm{Zn}$. Fragment of a leaf mesophyll cell from the control material with a thin layer of cytoplasm surrounding the transparent vacuoles adhering to a typical cell wall. An ellipsoid chloroplast with regularly organized grana and a small starch grain, a mitochondrium with a matrix of electron density similar to cytoplasm with narrow cristae (a). A fragment of a mesophyll cell from $50 \mathrm{Zn}$-treated material containing a chloroplast with slightly changed organization of thylakoids, condensed type of mitochondria and a fragment of electron-transparent vacuole (b). A fragment of a mesophyll cell from $300 \mathrm{Zn}$-treated material with symptoms of plasmolysis (arrow) and slightly thinned down cytoplasm, an electrontransparent vacuole, a chloroplast with dense stroma, not regular thylakoid organisation and large starch grains forming protrusion (asterisk) and a mitochondrium with low-density matrix and narrow cristae (c). A fragment of a mesophyll cell from $300 \mathrm{Zn}$-treated materials with slightly thinned down cytoplasm, an electron-transparent vacuole, a chloroplast with disorganised thylakoid system and a protrusion (asterisk), changed in shape mitochondria with swollen cristae and condensed matrix (d). $C h$ chloroplast, $C W$ cell wall, $M$ mitochondrium, $S$ starch, $V$ vacuole

structures were identified in a confocal microscope using a specific $\mathrm{Zn}$ indicator (Azzarello et al. 2012).

It is known that accumulation of heavy metals in vacuoles and cell walls is the strategy to avoid metal induced toxicity (Frey et al. 2000). In Thlaspi caerulescens (Frey et al. 2000) and in Potentilla griffithi (Hu et al. 2009) $\mathrm{Zn}$ was accumulated in cell walls of root cortical cells. Zn presence in this compartment is usually accompanied with thickening of a cell wall (Jin et al. 2008; Liu et al. 2014), which together with increased cation exchange capacity, acts as an external barrier limiting $\mathrm{Zn}$ entry into a protoplast (Muschitz et al. 2009). It was also proved that proteins as well as cellulose, hemi-cellulose and pectins were $\mathrm{Zn}$-binding components of plant cell walls (Sarret et al. 2009; Reboredo 2012). Zn localization mainly in vacuoles was observed in Sedum alfredi root cells (Jin et al. 2008). In vacuoles, $\mathrm{Zn}$ is usually bound to organic acids, mainly citrate that strongly binds metal ions (Frey et al. 2000; Broadley et al. 2007). The excess of metal is therefore safely stored there which prevents it from disturbing important metabolic processes in cytoplasm and organelles. In T. aestivum treated with $50 \mathrm{Zn}$ there were only adaptive changes of root meristem cell structure. More numerous Golgi apparatus vesicles and thicker wavy cell wall suggested intensified process of cell wall component synthesis aiming at increasing the capacity of apoplast to sequestrate metal excess. Increased number of vacuoles filled with deposits indicated metal trapping. The cell ultrastructure did not show any degenerative changes which suggested that these mechanisms were effective. The only organelles significantly different from the control were mitochondria. The condensed form of mitochondria occurs when ADP level exceeds that of ATP for example due to inhibited oxidative phosphorylation. Such change was also induced by zinc excess in $P$. tomentosa (Azzarello et al. 2012). This type of structural alternations

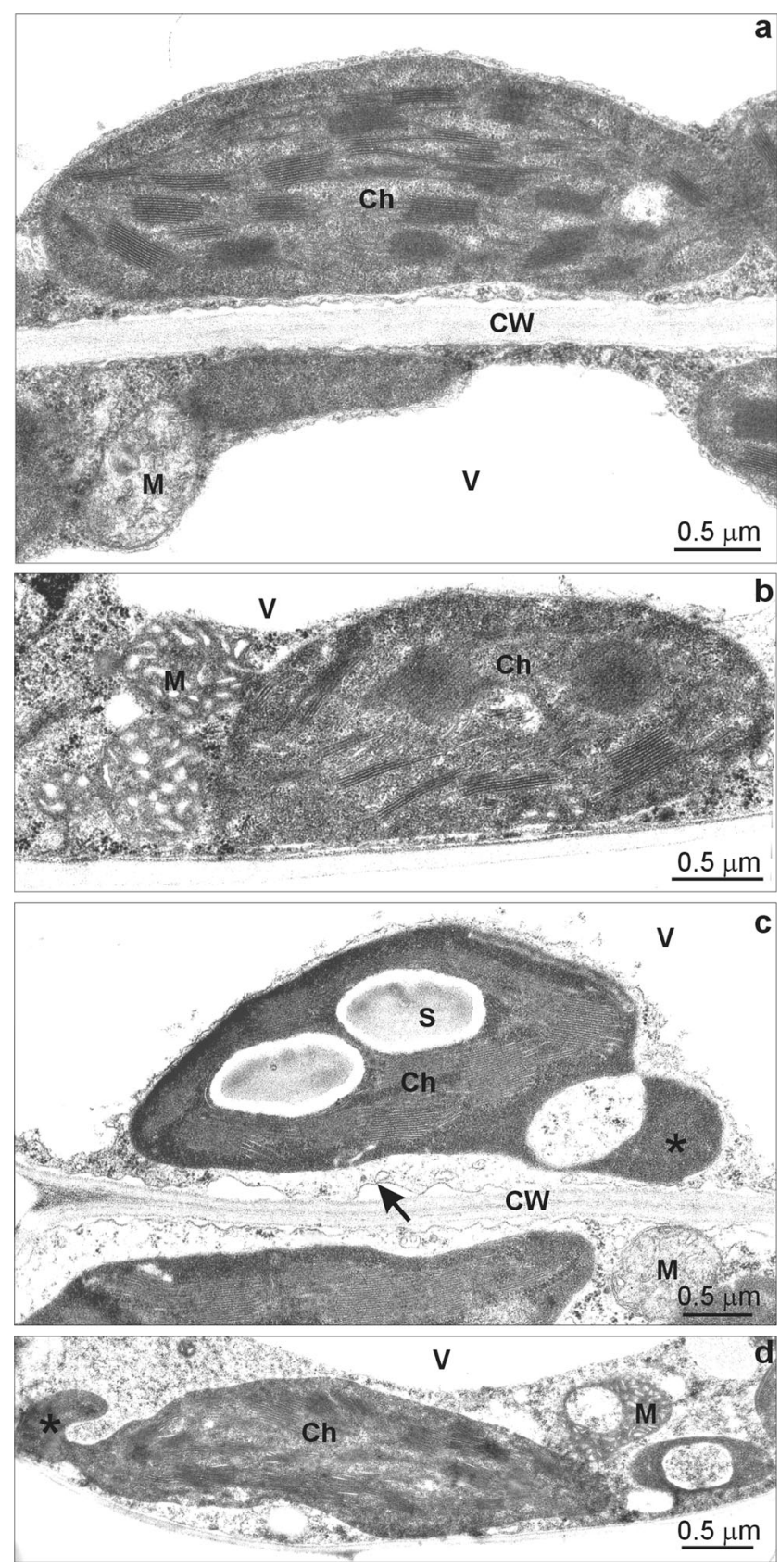

might be also trigged by imbalance of $\mathrm{Fe}$ and $\mathrm{Cu}$ ions observed in Zn-treated T. aestivum that could affect functioning of respiratory electron transport chain (Palmer and Guerinot 2009).

The nucleolar vacuoles which were present in 300 $\mathrm{Zn}$ treated $T$. aestivum cells suggested enhanced transcriptional activity in them. They are typical of plants in which the production of ribosomal ribonucleoproteins is lower than their migration into cytoplasm (Stepiński 2014). Vacuolated nuclei were also observed in root cells of Zn-treated Nigella sativa (El-Ghamery et al. 2003). 
The first symptoms of wheat root cell degeneration processes i.e. thinned down cytoplasm with lipid droplets appeared at $300 \mathrm{Zn}$ which might suggest that sequestration mechanisms were insufficient. Excess of $\mathrm{Zn}$ disturbs cell membrane integrity (Tsonev and Lidon 2012). In nonhyperaccumulating Sedum alfredi ecotype disruption of plasma membranes and severe plasmolysis were observed at $100 \mu \mathrm{M} \mathrm{Zn}^{2+}$ (Jin et al. 2008). Membrane injury estimated by the level of malondialdehyde (MDA) was noticed after $\mathrm{Zn}$ treatment in R. sativus (Ramakrishna and Rao 2014), Camellia sinesis (Mukhopadhyay et al. 2013) and Hydrilla verticillata (Xu et al. 2013).

In mesophyll cells of $T$. aestivum plants treated with both tested $\mathrm{Zn}$ concentrations no electron dense deposits indicating $\mathrm{Zn}$ presence were observed in TEM, while in mesophyll cells of $P$. tomentosa such deposits were seen in vacuoles (Azzarello et al. 2012). On the other hand, $\mathrm{Zn}$ stored in vacuoles of leaf epidermal cells of $T$. cerulescens was evenly distributed and no $\mathrm{Zn}$ containing crystals or deposits were observed (Frey et al. 2000). In our research there were no visible $\mathrm{Zn}$ deposits in vacuoles of leaf mesophyll cells of T. aestivum, while high concentration of this ion was measured in aboveground parts of plants, however since $\mathrm{Zn}$ content analyses were made in whole T. aestivum shoots the precise place of $\mathrm{Zn}$ accumulation cannot be specified. In Saccharum ssp. treated with $\mathrm{Zn}$ at the concentrations ranging from 0.065 to $130 \mathrm{mg} \mathrm{L}^{-1}$ the metal content in leaf lamina was constant while in stalk it increased (Jain et al. 2010). Moreover, significant difference in $\mathrm{Zn}$ concentrations even between leaf blade tissues may occur. High level of this ion was measured in epidermis but not in mesophyll cells of $T$. cerulescens (Küpper et al. 1999) while in Arabidopsis halleri the situation was opposite (Zhao et al. 2000).

At the ultrastructural level the toxic effects of $\mathrm{Zn}$ on wheat mesophyll cells were noticed only at the metal concentration of $300 \mathrm{mg} \mathrm{L}^{-1}$. The symptoms of plasmolysis correlated with decrease in water content were noticed in that experimental variant. The significant plasmolysis of mesophyll cells was also observed in $H$. verticillata treated with $150 \mu \mathrm{M} \mathrm{Zn} \mathrm{(Xu}$ et al. 2013). The most evident effect of $Z n$ consisted in changes of mitochondria and especially chloroplast shape resulting in protrusions. The proposed function of chloroplast protrusions is better compound exchange due to greater area of contact between plastids, mitochondria and microbodies and it seems to be one of the protective mechanisms to avoid oxidative stress (Holzinger et al. 2007).

$\mathrm{Zn}$-triggered changes of chloroplast shape from ellipsoid to oval were visible in P. tomentosa (Azzarello et al. 2012) and S. alfredii (Jin et al. 2008) leaves together with starch and plastoglobule accumulation. In our experiment only increased number and size of starch grains were noticed. It suggests that in $T$. aestivum sugar metabolism was affected by the high $\mathrm{Zn}$ dose.
In other plant species the degenerative changes of mesophyll cell ultrastructure were observed at much lower Zn concentrations. In Camelia sinensis plants treated with $30 \mu \mathrm{M} \mathrm{Zn}$ chloroplasts had severely disorganised thylakoid system and swollen mitochondria (Mukhopadhyay et al. 2013). In 75- $\mu \mathrm{M}$ $\mathrm{Zn}$-treated $H$. verticillata chloroplast, mitochondria and a nucleus were seriously altered (Xu et al. 2013). Comparing the above results with those for T. aestivum one can see that wheat is rather tolerant to $\mathrm{Zn}$.

\section{Conclusions}

The results of our experiment indicate that $50 \mathrm{Zn}$ had no negative effects on $T$. aestivum while $300 \mathrm{Zn}$ was suppressive to plant growth. Although wheat treated with $50 \mathrm{Zn}$ took up relatively high amount of metal, no negative effects of that ion were noticed at the morphological and cytological levels. The probable results from the efficient adaptive modification, of root cell ultrastructure i.e. metal compartmentation in enlarged vacuoles. On the other hand, in spite of intensified metal sequestration in root cell vacuoles and even in cell walls in the plants treated with $300 \mathrm{Zn}$ the negative effects of the metal on plant growth were visible; however, there were no severe symptoms of cell degeneration. The depletion of growth parameters might result not only from direct toxic effect of the tested metal but also from energy consuming defensive processes and disturbed microelement homeostasis as well as decrease in water content.

Conflict of interest The authors declare that they have no conflict of interest.

Open Access This article is distributed under the terms of the Creative Commons Attribution 4.0 International License (http:// creativecommons.org/licenses/by/4.0/), which permits unrestricted use, distribution, and reproduction in any medium, provided you give appropriate credit to the original author(s) and the source, provide a link to the Creative Commons license, and indicate if changes were made.

\section{References}

Alloway BJ (2008) Zinc in soils and plant nutrition, 2nd edn. IZA and IFA Brussels, Belgium and Paris, France

Azzarello E, Pandolfi C, Giordano C, Rossi M, Mugnai S, Mancuso S (2012) Ultramorphological and physiological modifications induced by high zinc levels in Paulownia tomentosa. Environ Exp Bot 81: $11-17$

Broadley MR, White PJ, Hammond JP, Zelko I, Lux A (2007) Zinc in plants. New Phytol 173:677-702

Cakmak I (2009) Enrichment of fertilizers with zinc: an excellent investment for humanity and crop production in India. J Trace Elem Med Biol 23:281-28 
Caldelas C, Araus JL, Febrero A, Bort J (2012) Accumulation and toxic effects of chromium and zinc in Iris pseudacorus L. Acta Physiol Plant 34:1217-1228

Doncheva S, Stoyanova Z, Velikova V (2001) Influence of succinate on zinc toxicity of pea plants. J Plant Nutr 24:789-804

El-Ghamery AA, El-Kholy MA, Abou El-Yousser MA (2003) Evaluation of cytological effects of $\mathrm{Zn}^{2+}$ in relation to germination and root growth of Nigella sativa L. and Triticum aestivum L. Mutat Res 537:29-41

Frey B, Keller C, Zierold K, Schulin R (2000) Distribution of Zn in functionally different leaf epidermal cells of the hyperaccumulator Thlaspi caerulescens. Plant Cell Environ 223:675-687

Gondek K, Kopeć N, Głąb T (2012) The contents of microelements and exogenous amino acids in spring wheat (Triticum aestivum $\mathrm{L}$.) grain after municipal sewage sludge fertilization. J Agric Sci 4:294-303

Holzinger A, Buchner O, Lutz C, Hanson MR (2007) Temperaturesensitive formation of chloroplast protrusions and stromules in mesophyll cells of Arabidopsis thaliana. Protoplasma 230:23-30

Hu PJ, Qiu RL, Senthikulmar P, Jiang D, Chen ZW, Liu FJ (2009) Tolerance, accumulation and distribution of zinc and cadmium in hyperaccumulator Potentilla griffithii. Environ Exp Bot 66:317-325

Jain R, Srivastava S, Solomon S, Shrivastava AK, Chandra A (2010) Impact of excess zinc on the growth parameters, cell division, nutrient accumulation, photosynthetic pigments and antioxidative stress of sugarcane (Saccharum spp.). Acta Physiol Plant 32:979-986

Jin XF, Yang XE, Islam E, Liu D, Mahmood Q, Li H, Li J (2008) Ultrastructural changes, zinc hyperaccumulation and its relation with antioxidants in two ecotypes of Sedum alfredii Hance. Plant Physiol Biochem 46:997-1006

Küpper H, Zhao FJ, McGrath SP (1999) Cellular compartmentation of zinc in leaves of the hyperaccumulator Thlaspi caerulescens. Plant Physiol 119:305-311

Liu D, Chen J, Mahmood Q, Li S, Wu J, Ye Z, Peng D, Yan W, Lu K (2014) Effect of Zn toxicity on root morphology, ultrastructure, and the ability to accumulate $\mathrm{Zn}$ in Moso bamboo (Phyllostachys pubescens). Environ Sci Pollut Res 21:13615-13624

Mangal M, Agarwal M, Bhargava D (2013) Effect of cadmium and zinc on growth and biochemical parameters of selected vegetables. J Pharmacogn Phytochem 2:106-113

Mukhopadhyay M, Das A, Subba P, Bantawa P, Sakrar B, Ghosh P (2013) Structural, physiological, and biochemical profiling of tea plants under zinc stress. Biol Plant 57:474-480

Muschitz A, Faugeron C, Morvan H (2009) Response of cultured tomato cells subjected to excess zinc: role of cell wall in zinc compartmentation. Acta Physiol Plant 31:1197-1204
Palmer CM, Guerinot ML (2009) Facing the challenges of $\mathrm{Cu}, \mathrm{Fe}$ and $\mathrm{Zn}$ homeostasis in plants. Nat Chem Biol 5:333-340

Ramakrishna B, Rao SSR (2014) Foliar application of brassinosteroids alleviates adverse effects of zinc toxicity in radish (Raphanus sativus L.) plants. Protoplasma. doi:10.1007/s00709-014-0714-0

Reboredo F (2012) Zinc compartmentation in Halimione portulacoides (L.) Aellen and some effects on leaf ultrastructure. Environ Sci Pollut Res 19:2644-2657

Reynolds ES (1963) The use of lead citrate at high $\mathrm{pH}$ as an electronopaque stain in electron microscopy. J Cell Biol 17:208

Richard $\mathrm{O}$, Pineau $\mathrm{C}$, Loubet $\mathrm{S}$, Chalies $\mathrm{C}$, Vile $\mathrm{D}$, Marquès L, Berthomieu P (2011) Diversity analysis of the response to $\mathrm{Zn}$ within the Arabidopsis thaliana species revealed a low contribution of $\mathrm{Zn}$ translocation to $\mathrm{Zn}$ tolerance and a new role for $\mathrm{Zn}$ in lateral root development. Plant Cell Environ 34:1065-1078

Sagardoy R, Morales F, López-Milán AF, Abadia A, Abadia J (2009) Effect of zinc toxicity on sugar beet (Beta vulgaris L.) plants grown hydroponics. Plant Biol 11:339-350

Sarret G, Willems G, Isaure MP, Marcus MA, Fakra SC, Frérot H, Pairis S, Geoffroy N, Menceau A, Saumitou-Laprede P (2009) Zinc distribution and speciation in Arabidopsis hallerix Arabidopsis lyrata progenies presenting various zinc accumulation capacities. New Phytol 184:581-595

Stępiński D (2014) Functional ultrastructure of plant nucleolus. Protoplasma 251:1285-1306

Szczepocka A (2005) Criteria for estimating soil pollution from heavy metals. Zeszyty Naukowe SGSP 32:13-27

Tsonev T, Lidon FJC (2012) Zinc in plants - an overview. Emirates J Food Agric 24:322-333

Xu Q, Chu W, Qiu H, Fu Y, Cai S, Sha S (2013) Responses of Hydrilla verticullata (L.f.) Royle to zinc: in situ localization, subcellular distribution and physiological and ultrastructural modifications. Plant Physiol Biochem 69:43-48

Yang Y, Sun C, Yao Y, Zhang Y, Achal V (2011) Growth and physiological responses of grape (Vitis vinifera "Combier") to excess zinc. Acta Physiol Plant 33:1483-1491

Zeng XW, Ma LQ, Qiu RL, Tang YT (2011) Effects of Zn on plant tolerance and non-protein thiol accumulation in $\mathrm{Zn}$ hyperaccumulator Arabis paniculata Franch. Environ Exp Bot 70: 227-232

Zhao F, Lombi E, Breedon T, McGrath S (2000) Zinc hyperaccumulation and cellular distribution in Arabidopsis halleri. Plant Cell Environ 23:507-514 